1910. Crawford, J. C. Proc. U. S. Nat. Mus., 38, May 3.

Brues, C. T. Psyche, XVII, June.

Fiske, W. F. Parasites of the Gypsy and Brown-tail Moths introduced into Massachusetts. Boston (State Forester's Office), p. 55, table V.

Fiske, W. F. and A. F. Burgess. Jour. Econ. Ent., III, October.

Gahan, A. B. Canadian Eut.

Girault, A. A. Journ. N. Y. Ent. Soc., XVIII, December.

Howard, L. O. Bull. Bur. Ent. Tech. Ser., No. 19, U. S. Dept. Agric., January.

Johnson, F. and A. G. Hammar. Bull. Bur. Ent., No. 89, U. S. Dept. Agric.

\title{
TWO NEW NAMES OF SPHECOID WASPS.
}

\section{By S. A. Rolwer,}

U. S. National Museum, Washington, D. C.

The following two names purposed by Billberg in 1820 have generally been overlooked by Hymenopterists.

\section{Genus Ammobia Billberg.}

Ammobia Billberg, Enumartio Insectorum, 1820, p. 105.

Type--Pepsis argcntata Fabricius.

Chlorion (Ammobia) umbrosum (Christ.).

Syn.-Proterosphex H. Fernald. Ent. News, vol. 16, 1905, p. 165.

This genus was originally treated as follows (Eg. equals Billberg):

"G. Ammobia Eg.-Amophila Krb. Latr. Ed. cuc.-Pepsis Fbr.Spnl.-Miscus Jur.-Sphex Auct. coet.

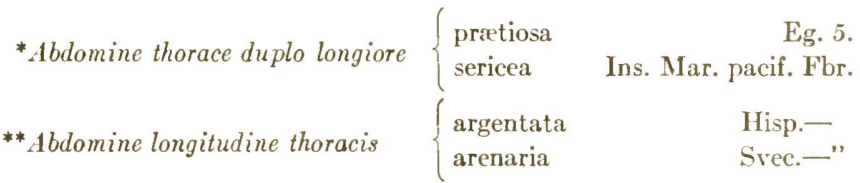

The first species included, protiosa Billberg, is a nomen nudum. The second species, Pepsis sericea Fabricius, is a variety of Sphex (F. F. Kohl) aurulentus oceurring in the West Indies so probably was not before Billberg and should not be taken as the type.

The third species, Pepsis argentata Fabricius, is a common European species; is a synonym of Sphex (F. F. Kohl) umbrous, and may be chosen as the type of Ammobia. 
The fourth species, Pepsis arenaria Fabricius, is a synonym of Sphex (Ammophila Kirby and Auctorum) (Psammophila) hirsuta.

Inasmuch as either Psammophila Dahlbom (1842) or Proterosphex Fernald (1905) would have to fall as a synonum of Ammobia Billberg it has seemed advisable to choose the latter name as the synonym, so the first species which could with propriety be chosen as the type of Billberg's genus is here designated as such.

After carefully reviewing the case of Sphex versus Ammophila, I can do nothing but agree with Dr. H. Fernald, and unless some earlier designation for the types of the genera in question can be found, I can see no way this change can be avoided. The objection offered by Dr. F. F. Kohl ${ }^{1}$ only serves to put off the day when our nomenclature will be put on a firm basis.

\section{Genus Lestica Billberg.}

Lestica Billberg, Enumeratio Insectorum, 1820, p. 107.

Type.-Crabro subterraneus Fabricius.

Syn. Ceratocolus Lepeletier, Ann. Ent. Soc. France, vol. 3, 183t, p. 739.

Originally treated thus: (Eg. equals Billberg.)

'G. Lestica Eg.--Sphex Linn. VII.-Yespa Linn. Gffr.-Crabro Auct. pler.

subterranea Svec. Fbr. fossoria Svec. Linn.

peltata $\quad 6$ cincta $\quad-$ Fbr.

cribaria Linn. alata Germ. Pnz.

clypeata dimidata

Included species:

1. Crabro subterraneus Fabricius, a common European spccies which may be chosen as the type; placed in Ceratocolus by Dahlbom in 1845 .

2. Crabro peltata Fabricius, said to be a synonym of cribrarius Linnæus.

3. Vespa cribrarius Linnæus, designated as the type of Crabro in 1837.

4. Sphex clypeata Linnæus, a common European species: placed Thyreus in $\mathbf{1 8 6 4 .}$

5. Sphex fossorius Linnaus, a well-known species; placed in Solenius in 1870, and erroneously chosen as the type of Crabro in 1899 .

1 Ann. k. k. Naturhist.' IIofmus. Wien Bd. 21, 1906, pp. 228-229. 
6. Crabro sexcinctus Fabricius, a well-known species; placed in Solenius in $185^{\circ}$.

7. Crabro alatus Panzer, a common species; placed in Ceratocolus in 1834 and chosen as the type of the same genus in 1899.

8. There is no dimidata Panzer.

Crabro subterraneus is chosen as the type because it is the first well-known species included. It is consubgeneric with Crabro alatus Panzer, the designated type of Ceratocolus, hence the above cited synonymy. 

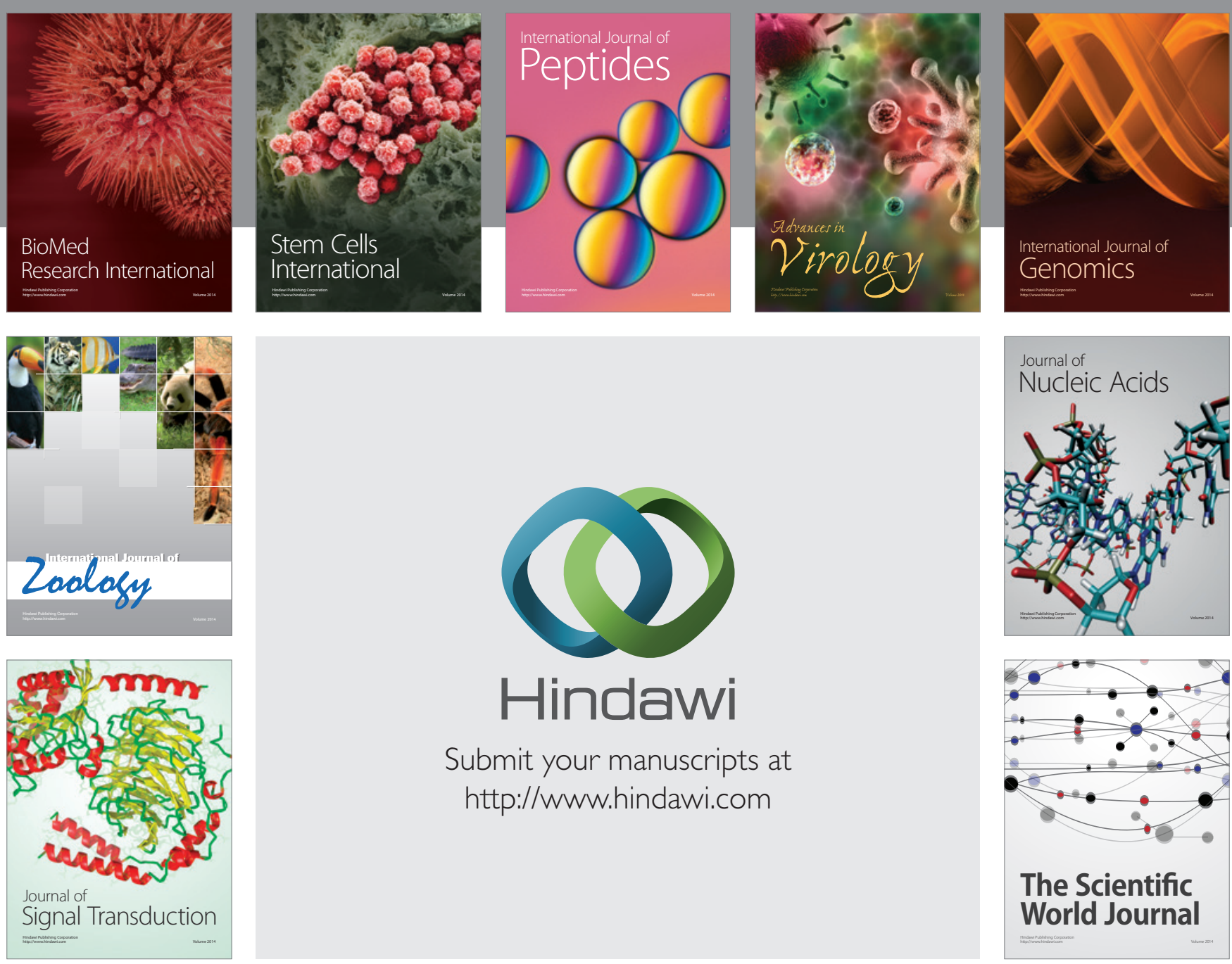

Submit your manuscripts at

http://www.hindawi.com
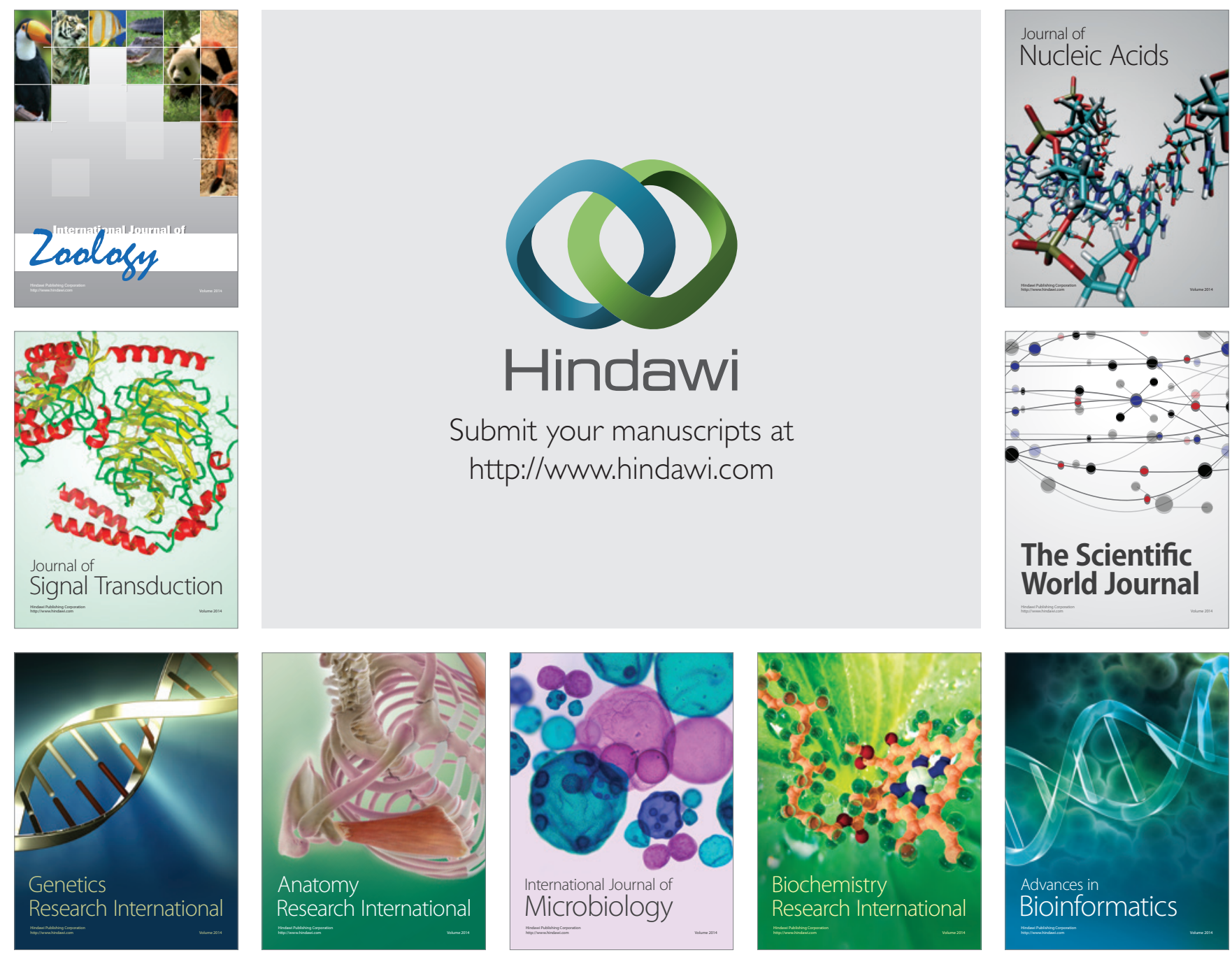

The Scientific World Journal
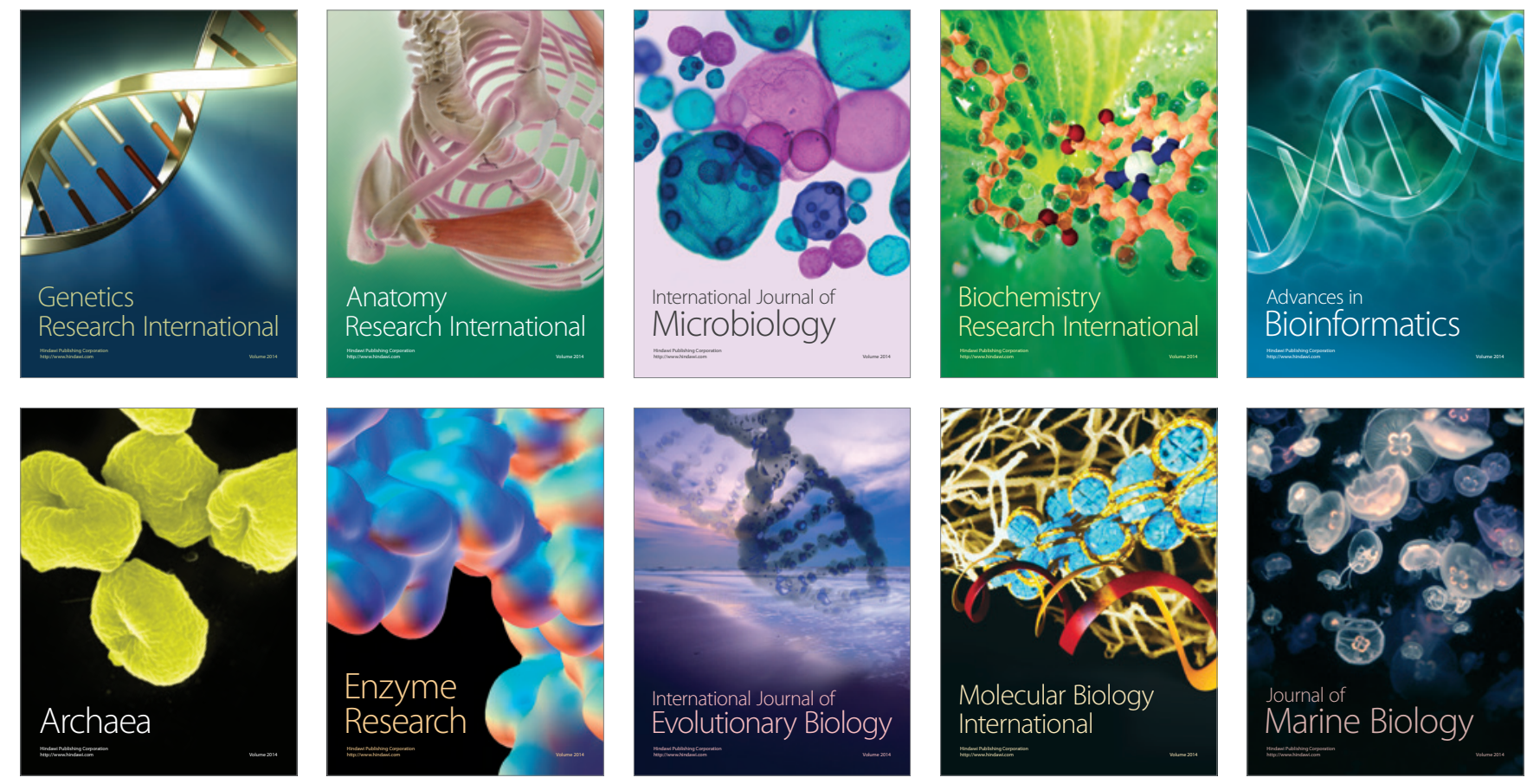